\title{
Levels of Heavy Metals in Ground Water from Chantan Dump Site in Ghana
}

\author{
Boakye Sandra* ${ }^{1}$, Jonfia-Essien William ${ }^{2}$, Otu Solomon Ayeboafo ${ }^{1}$, Anoumba \\ Vouma Maixant Junior ${ }^{1}$ \\ ${ }^{I}$ Radford University College. Department of Applied Science. P.O.BOX CT 2837 Cantoments Accra Ghana; \\ ${ }^{2}$ Quality Control Company Ltd, (COCOBOD). P. O. Box M54. Accra
}

\begin{abstract}
A study was undertaken to determine the concentrations of heavy metals in the ground water from landfill leachiest in Chantan, a suburb of Accra. Six wells were excavated from the Dump site and the concentrations for heavy metal such as copper, chromium, arsenic and zinc were monitored using wet digestion technique. $\mathrm{HCl}$ and $\mathrm{HNO}_{3}$ were used followed by atomic absorption spectrophotometry. The heavy metals were quantified using external calibration with standards. Copper had the highest mean concentration of $1.410 \mathrm{mg} / \mathrm{l}$ in water from well three (3). This is above the maximum admissible and desirable limit set by the World Health Organization (WHO), an international organization. Chromium recorded the minimum mean concentration of $0.002 \mathrm{mg} / \mathrm{l}$ and this was found in wells (2) and (3). Generally, the study revealed that $83.3 \%$ of water samples had mean concentrations below the WHO maximum admissible and desirable limit.
\end{abstract}

Keywords: Pollution: Heavy metal: Atomic Absorption spectrophometry: Ground water: World Health Organization.

\section{Introduction}

Groundwater accounts for about $98 \%$ of the world's fresh water resources and it is well distributed throughout the earth (Bouwer, 2002). Over the years, groundwater has served as a potential source of water supply. According to Ajibade et al., (2011), 90\% of the population depend largely on hand-dug wells. However, the quality of ground water has been affected by human activities. More than one billion people in the world do not have suitable drinking water and statistics show that about three to five millions die annually from waterrelated diseases (Kumar and Singh, 2006). In the hydrological cycle, less than $0.1 \%$ of the metals are actually dissolved in the water and more than 99.9\% are stored in sediments and soils (Karbassi et al., 2007, Pradit et al., 2010). The migration of heavy metals in groundwater is largely controlled by $\mathrm{pH}$, amount of metal, cation exchange (Martinez and Motto, 2000), organic carbon content, oxidation state of mineral components as well as the redox potential of the ground water system (Sherene, 2010).

Heavy metals are among the major pollutants of water sources (Marcovecchio et al., 2007). The contamination of ground water by heavy metals has also assumed great significance during recent years due to their toxicity, bio concentration and bio accumulation in food chain. Heavy metals possess serious effects on human health and might cause various symptoms depending on the type and amount of the metal involved (Adepoju-Bello and Alabi, 2005). Due to the toxicity of heavy metals in water, guidelines for heavy metals in drinking water have been set by different International organizations such as WHO, EPA and the European Union Commission. Monitoring programs have therefore been established to regulate heavy metal concentrations in ground water sources, ensure compliance with national and international law, and to reassure consumers that drinking water is safe for consumption. There is need to continuously assess the quality of ground water sources to ensure that their concentrations conform with international standards (Ehi-Eromosele and Okiei, 2012).

\subsection{The study area}

\section{Methodology}

Chantan is situated in Greater Accra region of Ghana. Its geographical coordinates are $5^{\circ} 37^{\prime} 0$ '” North, $0^{\circ} 15^{\prime}$ " " 'West. Chantan market which used to be a open dumpsite was shut down in 2009 due to urbanization. The geology of the study area is made of acrisols which have Ph less than 7. 

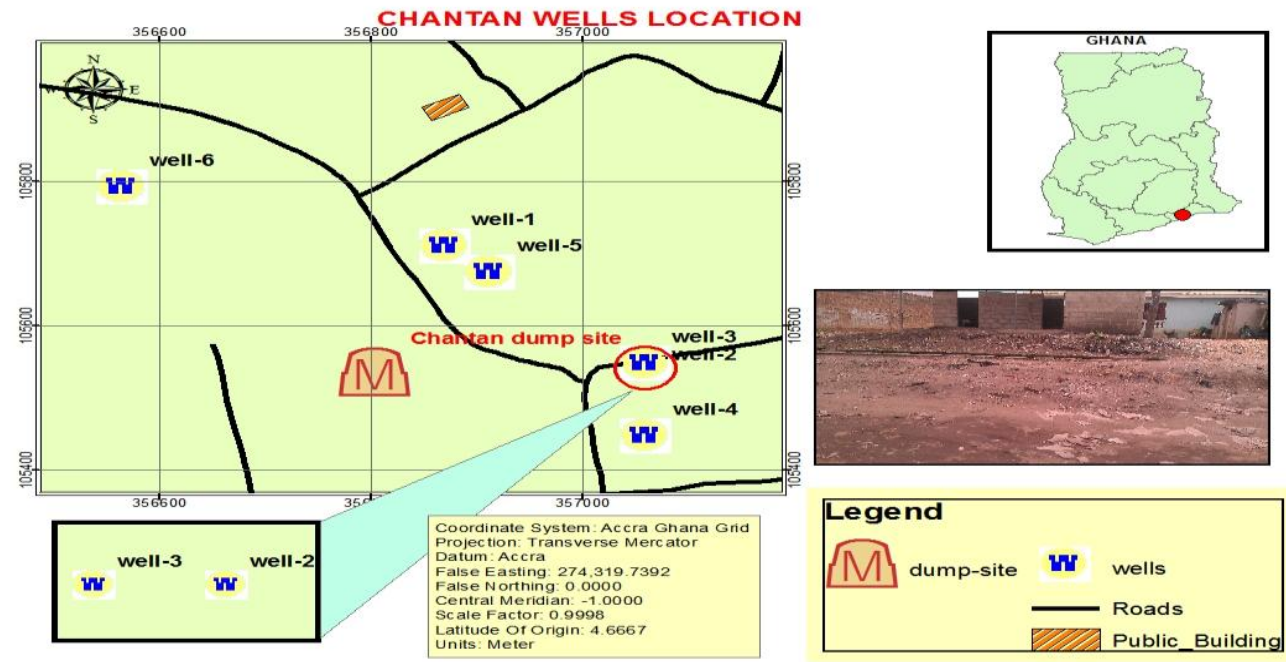

\subsection{Reagents and apparatus}

Hydrochloric acid and nitric acid were analytical grade from BDH England, hydrogen peroxide was analytical grade from MERCK Darmstadt, Germany. deionised water, certified calibration standards (BDH England), $250 \mathrm{ml}$ plastic bottles, flame atomic absorption spectrophotometer (Perkin Elmer 5100 PC), Whatman 4 filter paper $(0.45 \mu \mathrm{m})$, Ph meter, conductivity meter and temperature probe (vernier software and technology).

\subsection{Determination of $\mathrm{p} \mathrm{H}$, electrical conductivity and temperature}

The electrical conductivity electrode was calibrated using sodium chloride solution of $12880 \mu \mathrm{S} / \mathrm{cm}$. It was rinsed with deionised water and immersed into $50 \mathrm{ml}$ of the water sample. The electrode was slowly moved in a circle for one minute until the digital readout stabilized. The probe was placed in the samples and the meter set to measure temperature. The process was repeated three times for all other water samples. For $\mathrm{Ph}$ measurements the electrode was calibrated with sodium chloride buffer solution at ph of 4.0, 7.0 and 9.0 respectively. The electrode was rinsed with deionised water and then immersed into $50 \mathrm{ml}$ water samples. Measurements were allowed to stabilize and recorded.

\subsection{Sampling}

The study was conducted between February and March 2015. Water samples were taken from six wells within the sampling area beginning from the least suspected contaminated area. Prior to sample collection, all bottles were washed with detergents, dilute nitric acid and distilled water and dried in an oven. Water samples were collected using a rubber bucket tied to a rope. About $5 \mathrm{~L}$ of bulk saple was collected from all the six wells in a large plastic bowl after agitation of water to obtain a homogenous sample. Before taking the water samples, the $250 \mathrm{ml}$ plastic bottles were rinsed three times with the water to be collected. Water samples were transferred into the sterilized $250 \mathrm{ml}$ plastic bottles. About $2 \mathrm{ml}$ of $10 \% \mathrm{HNO}_{3}$ was added to each bottle as a preservative (Singh et al., 2010). The water samples were labeled and kept in an ice chest and then transported to the laboratory for storage in a refrigerator at about $4{ }^{\circ} \mathrm{C}$ before analysis.

\subsection{Laboratory analysis}

The water samples were digested using concentrated nitric acid according to Zhang (2007). $5 \mathrm{ml}$ of the digested sample was filtered through a Whatman filter paper $(0.45 \mu \mathrm{m})$ and diluted to $100 \mathrm{ml}$ with deionised water and stored at $4{ }^{0} \mathrm{C}$ for analyses.

\subsection{Analysis of anions}

Chloride ions concentration in the water samples was ascertained by titration using $0.27 \mathrm{M} \mathrm{K}_{2} \mathrm{CrO}_{4}$ indicator and $0.1 \mathrm{M} \mathrm{AgNO}_{3}$. Sulphate ion solution was converted to barium sulphate and analysed by spectrophotometer at wavelength of maximum absorbance of $420 \mathrm{~nm}$ (USEPA, 1983). The concentration of the sulphate ions was then determined from a calibrated curve prepared from standard $\mathrm{Na}_{2} \mathrm{SO}_{4}$ solution. Nitrate ion concentration in the water samples were determined with the aid of spectrophotometer using the Cadmium reduction method (HACH, 1992). 


\subsection{Preparation of standards}

Mixture of standard solution of selected metals (MIX 1) was prepared for $\mathrm{Zn}, \mathrm{As}, \mathrm{Cu}$ and $\mathrm{Cr}$ of concentration $1000 \mathrm{mg} / \mathrm{l}$ by dissolving their high purity metal salts in $0.5 \% \mathrm{HNO}_{3}$. Serial dilutions were made from stock solution to produce calibration standards of concentrations $0.2,0.4,0.6$ and $0.8 \mathrm{mg} / \mathrm{l}$ respectively which were labeled as standard (MIX 1, MIX2, MIX 3 and MIX 4)

Table 1: Results of concentrations of heavy metals calibration standards

\begin{tabular}{|c|c|c|}
\hline STANDARD & CONCENTRATION mg/I & ABSORBANCE \\
\hline MIX 1 & 0.2 & 0.025 \\
\hline MIX 2 & 0.4 & 0.049 \\
\hline MIX 3 & 0.6 & 0.073 \\
\hline MIX 4 & 0.8 & 0.995 \\
\hline
\end{tabular}

\subsection{Instrumental analysis}

The concentrations of $\mathrm{Zn}, \mathrm{As}, \mathrm{Cu}$ and $\mathrm{Cr}$ were determined with atomic absorption spectrophotometer (Perkin Elmer 5100 PC) using standard guidelines by APHA, AWWA, WEF 2001. A calibration curve was constructed and the concentration equivalent to the absorbance of the sample was read from the curve and recorded accordingly.

\subsection{Quality assurance}

Blanks were prepared and carried throughout the entire sample preparation and analytical process to determine whether samples were contaminated. Replicate samples were used to determine precision of results. Samples were spiked with $0.2,0.5$ and $1.0 \mathrm{mg} / \mathrm{l}$ of standard MIX solution to determine the recovery.

$$
\text { Recovery }=\frac{\text { Amount of analyte recovered }}{\text { Amount of analyte spiked }} \times 100
$$

\section{Results and Discussion}

The fate and transport of a metal in groundwater depends significantly on the chemical form and speciation of the metal (Allen et al., 1991). The mobility of metals in ground-water systems is hindered by reactions that cause metals to be adsorbed. These mechanisms can retard the movement of metals and also provide a long-term source of metal contaminants (NRC, 1994). While the various metals undergo similar reactions in a number of aspects, the extent and nature of these reactions varies under particular conditions. After discharge to an aquatic environment metals are partitioned between solid and liquid phases. Partitioning is affected strongly by variations in $\mathrm{pH}$, redox state, organic content, and other environmental factors (Salomons, 1995). Chromium concentrations were above WHO limits of $0.005 \mathrm{mg} / \mathrm{l}$ in well 1 at ph 6.1 (Table 2 and 3). Most heavy metals are adsorhed at high Ph. However, literature reveals that ph range of 4 to 5 decreases the solubility and migration of chromium in water (Chrotowski et al., 1991) which may be due to presence of clay, iron and aluminium oxides as well as organic matter content. Most of chromium released into natural waters is particle associated, however, and is ultimately deposited into the sediment (Smith et al, 1995). In contaminated areas, $\mathrm{Cr}$ concentrations are commonly 300 to $500 \mathrm{mg} / \mathrm{l}$ (CRWQCB, 2000; Maxwell, 1997) and have been reported to reach $14 \mathrm{~g} / \mathrm{l}$ (Palmer and Wittbrodt, 1991)

Table 2: Comparison of physical parameters of groundwater samples with WHO standards

\begin{tabular}{|c|c|c|c|}
\hline LOCATION & $\begin{array}{c}\text { MEAN } \\
\mathbf{p ~ H}\end{array}$ & $\begin{array}{c}\text { MEAN ELECTRICAL CONDUCTIVITY } \\
\boldsymbol{\mu S / c m}\end{array}$ & $\begin{array}{c}\text { MEAN TEMPERATURE } \\
{ }^{\circ} \mathbf{C}\end{array}$ \\
\hline WELL 1 & 6.1 & 1200 & 28.5 \\
\hline WELL 2 & 6.8 & 1250 & 33 \\
\hline WELL3 & 6.5 & 1000 & 31 \\
\hline WELL 4 & 6.7 & 1500 & 32 \\
\hline WELL5 & 6.9 & 1620 & 31.8 \\
\hline WELL 6 & 6.9 & 1400 & 30.5 \\
\hline WHO LIMITS(2011) & $6.5-8.5$ & 500 & \\
\hline
\end{tabular}

Table 3: Results of heavy metal concentrations in ground water samples from six wells in Chantan (mg/l)

\begin{tabular}{|l|l|l|l|l|}
\hline & \multicolumn{4}{l|}{ MEAN CONCENTRATON \pm SD in $\mathbf{~ m g / L ~}$} \\
\hline WELL & Cr & As & Zn & Cu \\
\hline $\mathbf{1}$ & $0.081 \pm 0.006$ & $0.108 \pm 0.008$ & $0.008 \pm 0.001$ & $0.903 \pm 0.042$ \\
$\mathbf{2}$ & $0.002 \pm 0.001$ & $0.012 \pm 0.010$ & $0.009 \pm 0.001$ & $1.073 \pm 0.042$ \\
\hline $\mathbf{3}$ & $0.002 \pm 0.001$ & $0.118 \pm 0.026$ & $0.006 \pm 0.001$ & $1.410 \pm 0.036$ \\
\hline $\mathbf{4}$ & $0.041 \pm 0.010$ & $0.007 \pm 0.008$ & $0.006 \pm 0.001$ & $0.873 \pm 0.025$ \\
\hline $\mathbf{5}$ & $0.009 \pm 0.001$ & $0.007 \pm 0.002$ & $0.006 \pm 0.002$ & $0.850 \pm 0.075$ \\
\hline $\mathbf{6}$ & $0.005 \pm 0.001$ & $0.008 \pm 0.001$ & $0.009 \pm 0.001$ & $0.938 \pm 0.035$ \\
\hline WHO LIMIT (2011) & 0.050 & 0.010 & 5.000 & 2.000 \\
\hline
\end{tabular}


Concentrations of As in well 1, 2 and 3 were relatively higher than recommended values of $0.01 \mathrm{mg} / \mathrm{l}$ by WHO (Table 3). This may be attributed to increase in temperature of water which facilitates the migration of heavy metals in water. When the temperature increases metal activity in the water may be high and has faster migration rates. Yu Ling et al., (1998) concluded that considerable enrichment of heavy metals in the submicron range occurs during vaporization of heavy metals in the high temperature environment and the subsequent condensation in lower temperature regions of the systems. In addition, arsenic mobility increases as $\mathrm{pH}$ increases (Smith et al., 1995). The effective desorption of As from adsorbent could be achieved using a mixed solution of $\mathrm{Cl}^{-1}$ and $\mathrm{OH}^{-1}$ (Elizalde-Gonzalez et al., 2001; Lenoble et al., 2002). Arsenic can readily combine with other elements, and inorganic arsenic compounds are formed when arsenic combines with elements such as chloride and sulfur compounds (OSHA, 2004). The elevated concentrations of As were related to high $\mathrm{Cl}^{-1}$ and $\mathrm{SO}_{4}^{-2}$ in water (table 4). Erickson and Barnes (2005) stated that in the upper Midwest, USA, elevated arsenic concentrations in public drinking water systems, where twelve percent of public water systems were located exceed $10 \mu \mathrm{g} / \mathrm{l}$, the USEPA drinking water guideline value for arsenic. Recently, it has been reported that in Mexico, natural groundwater As contamination ranked 0.5 to $3.7 \mathrm{mg} / 1$ (Hossain, 2006). Marshall et al., (2007) found that drinking water in region II of Chile is supplied mainly by rivers that contain inorganic arsenic at very high concentrations. Kelepertsis et al., (2006) found elevated concentrations of As (125 $\mu \mathrm{g} / \mathrm{l}$ ) in the drinking water of Eastern Thessaly, Greece, while recently, Jovanovic et al. (2011) found that $63 \%$ of all water samples exceeded Serbian and European standards for arsenic in drinking water.

Table 4: Mean concentration of anions in six wells at Chantan

\begin{tabular}{|l|l|l|l|}
\hline \multicolumn{4}{|c|}{ MEAN CONCENTRATION \pm SD OF ANIONS } \\
\hline WELL & $\mathbf{C l}^{-\mathbf{1}}$ & $\mathbf{S O}_{\mathbf{4}}{ }^{-2}$ & $\mathbf{N O}_{\mathbf{3}}{ }^{-1}$ \\
\hline $\mathbf{1}$ & $352.37 \pm 10.21$ & $490.28 \pm 5.80$ & $1.98 \pm 0.05$ \\
\hline $\mathbf{2}$ & $308.53 \pm 7.80$ & $267.67 \pm 9.07$ & $1.65 \pm 0.31$ \\
\hline $\mathbf{3}$ & $411.13 \pm 9.92$ & $607.50 \pm 6.14$ & $1.57 \pm 0.03$ \\
\hline $\mathbf{4}$ & $264.30 \pm 8.22$ & $324.33 \pm 6.03$ & $1.70 \pm 0.03$ \\
\hline $\mathbf{5}$ & $316.97 \pm 6.21$ & $439.33 \pm 5.13$ & $1.59 \pm 0.02$ \\
\hline $\mathbf{6}$ & $517.23 \pm 7.51$ & $264.67 \pm 5.51$ & $1.44 \pm 0.02$ \\
\hline
\end{tabular}

The low concentrations of As in well 4, 5 and 6 may be due adsorption and co precipitation with hydrous iron oxides which are the removal mechanisms under most environmental conditions (Krause and Ettel, 1989; Pierce and Moore, 1982).

Concentrations of $\mathrm{Cu}$ and $\mathrm{Zn}$ were below the WHO limits of 5.0 and $2.0 \mathrm{mg} / \mathrm{l}$ respectively for all the wells samples in Chantan. Howell and Gawthorne (1987) discussed the important role of organic matter in the retention and behavior of copper. Igloria et al. (1997) included the possibility of formation of complexes between heavy metals and organic matter colloids in solutions, as well as those attached to soil surfaces. Sposito (1986), on the other hand, claimed that the effect of these colloids might retard metals transport. Clay carbonates, or manganese and hydrous oxides, readily adsorb zinc (Smith et al., 1995). The greatest percentage of total zinc in polluted ground water and sediment is associated with iron (Fe) and manganese (Mn) oxides. As with all cationic metals, zinc adsorption increases with $\mathrm{pH}$ and this is evident in table 1. Xu et al. (2006) reported that the mean concentrations of $\mathrm{Cu}$ and $\mathrm{Zn}$ in drinking water from Shangai, China were $0.29 \mathrm{mg} / \mathrm{l}$ and $0.91 \mu \mathrm{g} / \mathrm{l}$, respectively; which were lower than USEPA and WHO guideline values. On the contrary, high concentrations of $\mathrm{Cu}(88$ to $147 \mu \mathrm{g} / \mathrm{l})$ were found in bottled drinking waters sold in Canada (Dabeka et al., 2002).

\section{Conclusion}

From this study it can be concluded that $83.3 \%$ of heavy metals analyzed were below the WHO permissible levels for drinking water. Copper had the highest mean concentration of $1.410 \mathrm{mg} / \mathrm{l}$ in water from well three (3). Chromium recorded the minimum mean concentration of $0.002 \mathrm{mg} / \mathrm{l}$ and this was found in wells (2) and (3). There was a positive correlation for $\mathrm{Ph}$, temperature and conductivity with the concentrations of heavy metals recorded in wells in Chantan Dump site.

\section{Acknowledgement}

I appreciate the support and involvement of Dr William Jonfia Essien, Otu Solomon Ayeboafo and Anoumba Vouma Maixant Junior for their immense contribution in making this research a success.

\section{References}

[1]. Adepoju-Bello, A.A. and O.M. Alabi, 2005. Heavy metals: A review. The Nig. J. Pharm., 37: 41-45.

[2]. Ajibade, O. M., Omisanya, K. O. And Odunsi, G. O., (2011): Groundwater potability and flow directionof urban aquifer, Ibadan, SouthwesternNigeria;Journal of the Nigerian Association ofHydrogeologists, Volume 21, ISSN 0795-6495. Pp38-55APHAAWWA-WEF. (2001). Standard Methods for Examinations of Water and Wastewater, (22nd ed., pp. 4-146). Washington D.C. 
[3]. Allen, J.P and Torres, I.G. (1991), "Physical Separation Techniques for Contaminated Sediment," in Recent Developments in Separation Science, N.N. Li, Ed., CRC Press, West Palm Beach, FL, Vol V.

[4]. Bower, H.(2002): Artificial recharge of groundwater; Hydrology and Engineering; Hydrogeologist Journal 10(1).pp121-142

[5]. California Regional Water Quality Control Board (CRWQCB), 2000, Waste Discharge Requirements for In-Situ Pilot-Study for the Chemical Reduction of Cr, Order No. R1-2000-54.

[6]. Chrotowski, P.C., Durda, J.L., and Gdelmann, K.J (1991). The use of natural processes for the control of chromium migration. Remediation vol1 no 3 pp341-351

[7]. Dabeka, R., Conacher, H.B.S., Lawrence, J.F and Pepper, K. (2002). Survey of Bottled Drinking Waters Sold in Canada for Chlorate, Bromide, Bromate, Lead, Cadmium and Other Trace Elements. Food Additives and Contaminants 19(8):721-32

[8]. Ehi-Eromosele C. and Okiei W. (2012). Resources and Environment,2(3):82-86

[9]. Elizalde-Gonzalez, M.P., Mattusch, J., Einicke, W.D., Wennrich, R., 2001. Sorption on natural solids for arsenic removal. Chem. Eng. J. 81, 187-195.

[10]. Erickson, M.L. and Barnes, R.J. (2005). Glacial Sediment Causing Regional-Scale Elevated Arsenic in Drinking Water. Ground water pp 1-10

[11]. HACH, 1992. Water Analysis Handbook. Hach Company, Loveland, Colorado, USA, pp: 401-402, 427-428, 537-538.

[12]. Hossain MF (2006). Arsenic contamination in Bangladesh - An overview. Agro. Ecosystem Environ. 113:1-16.

[13]. Igloria, R.V., W.E. Hathhorn, Member, ASCE and D.R. Yonge. 1997. NOM and Trace Metal Attenuation During Storm-Water Infiltration. Journal of Hydrologic Engineering. Vol. 2, No. 3, pp. 120-127

[14]. Jovanovic D, Jakovijevic B, Ragic-Milutinovic Z, Paunovic K, Pekovic G, Knezevic T (2011). Arsenic occurrence in drinking water supply systems in ten municipalities in Vojvodine Region, Serbia. Environ. Res. 111:315-318.

[15]. Karbassi A., Ayaz G., Nouri J. 2007. Flocculation of trace metals during mixing of Talar river water with Caspian Seawater. International Journal of Environmental Research, 1(1), 66-73

[16]. Kelepertsis A, Alexakis D, Skordas K (2006). Arsenic, antimony and other toxic elements in the drinking water of Eastern Thessaly in Greece and its possible effects on human health. Environ. Geol. 50:76-84.

[17]. Krause, E. and Ettel V.A. (1989), "Solubilities and Stabilities of Ferric Arsenate Compounds,” Hydrometallurgy, 22 , pp. 311 -337.

[18]. Kumar R., Singh R.N. 2006. Municipal water and wastewater treatment. New Delhi: Capital Publishing Company

[19]. Lenoble, V., Bouras, O., Deluchat, V., Serpaud, B., Bollinger, J.C., 2002. Arsenic adsorption onto pillared clays and iron oxides. J. Colloid Interface Sci. 255, 52-58.

[20]. Marcovecchio, J.E., S.E. Botte and R.H. Freije, 2007. Heavy Metals, Major Metals, Trace Elements. In Handbook of Water Analysis. L.M. Nollet, 2 Ed. London: CRC Press, pp: 275-311

[21]. Marshall G, Ferreccio C, Yuan Y, Bates MN, Steinmaus C, Selvin S, Liaw J, Smith H (2007). Fifty-year study of lung and bladder cancer mortality in Chile related to arsenic in drinking water. J. Natl. Cancer I. 99:920-928

[22]. Martinez, C. E. and Motto, H. L. (2000). Solubility of lead, zinc andcopper added to mineral soils,Environmental Pollution, 107, no. 1, pp. $153-158$

[23]. Maxwell, C.R. (1997), Investigation and remediation of $\mathrm{Cr}$ and nitrate groundwater contamination: case study for an industrial facility, Journal of Soil Contamination, 6, 6, 733-749.

[24]. NRC (1994), Alternatives for Ground Water Cleanup, National Research Council, National Academy Press, Washington, D.C.

[25]. Occupational Safety \& Health Administration (OSHA). Arsenic. Retrieved 9/14/2011 from http://www.osha.gov/SLTC/arsenic/index.html

[26]. Palmer, C.D. and Wittbrodt, P.R., 1991, Processes affecting the remediation of Cr contaminated sites, Environmental Health Perspectives, 92, 25-40.

[27]. Pierce, M.L. and Moore, C.B. (1982), “Adsorption of Arsenite and Arsenate on Amorphous Iron Hydroxide,” Water Res., 16:12471253

[28]. Pradit S., Wattayakorn G., Angsupanich S., Baeyens W., Leermakers M. 2010. Distribution of trace elements in sediments and biota of Songkhla Lake,Southern Thailand. Water, Air, and Soil Pollution 6(1), 155-174.

[29]. Salomons W 1995. Environmental impact of metals derived from mining activities: Processes, predictions, prevention. Journal of Geochemical Exploration 52:5-23.

[30]. Singh A., Sharma R. K., Agrawal M. and Marshall F. M. (2010). Risk assessment of heavy Metal toxicity through contaminated vegetables from wastewater irrigated areas in Varanasi, India. Tropical Ecologhcal Issue 51. 2: 375-387.

[31]. Sherene. T (2010).Mobility and transport of heavy metals in polluted soil environment. Biological Forum — An International Journal, 2(2): 112-121

[32]. Smith, L.A., Means, J.L., Chen, A., Alleman, B., Chapman, C.C., Tixier, J.S., Jr., Brauning, S.E., Gavaskar, A.R., and Royer, M.D. (1995), Remedial Options for Metals-Contaminated Sites, Lewis Publishers, Boca Raton, FL.

[33]. Sposito, G. (1989), The Chemistry of Soils, Oxford University Press, New York

[34]. United States Environmental Protection Agency (USEPA), (1983). Method of Chemical analysis of Water and Wastewater, EPA/600/4-79/020, 374.3.1-375.4.3

[35]. Xu P, Huang SB, Wang ZJ, Lagos G (2006). Daily intakes of copper, zinc and arsenic in drinking water by population of Shangai, China. Sci. Total Environ. 362:50-55

[36]. Yu-Ling-Wei and Yu Ling Huang. (1998). Behaviour of sequential extraction of lead from thermally treated lead (II) Doped Alumina J. Environ. Qual. 27: 343-348

[37]. Zhang., C. (2007). Fundamental of environmental sampling and analysis. Wiley, New York, p 109 